\title{
The Teachers Registration Council, Decree 31 of 1993 and Its Implications for the Professionalisation of Teaching in Nigeria
}

\author{
Kingdom E. Orji, PhD; George Odua \\ Department of History \& Diplomatic Studies, Ignatius Ajuru University of Education, Rumuolumeni, Port \\ Harcourt, Rivers State, Nigeria. \\ Department of Secretarial Studies, Ignatius Ajuru University of Education, Rumuolumeni, Port Harcourt, Rivers \\ State, Nigeria.
}

\begin{abstract}
Teaching as a viable profession forms the bedrock of national development. But the status of the teacher in the Nigerian educational system has not been properly delineated vis-a-vis the critical issue of professionalism. This paper is an attempt to beam the searchlight on the functions of the Teachers Registration Council established by Degree No.31 with implications for the professionalization of teaching cum suggestions to make its objectives a reality.
\end{abstract}

\section{Introduction}

Teaching as a profession in Nigeria has become a controversial issue in the educational sector. The controversial nature of the debate arises from the fact that until the promulgation of Decree 31 of 1993, no clearcut definition and conditions have been evolved to characterize the status of stakeholders (i.e. practicing teachers) in the profession. In this vein Okeke (2004:15) observes that the problems of the teaching profession in Nigeria have national roots and in fact, teaching as a profession does not exist separately from the political, social and economic situation in the country. In this regards, Uya (2012:610) notes 'even the most cursory acquaintance with the Nigerian situation in the recent past shows clearly that although we have experienced, and are still experiencing crises in the political, economic, religious and social sectors of our national life, crises in the educational sector, because of their multiplier long term effects, represent perhaps the greatest threat to the survival of our fragile democracy. In Abuja, on January 10, 2013 the former Minister of Education, Professor Ruqqyyatu Rufai buttressed the need for the professionalization of the teaching profession as it will consolidate quality education and enjoined different states of the federation to support the Council under the leadership of the Chief Executive Secretary, Professor A. M Wokocha (http://www.nanngronline.com/section/general/ minister-restates.com)

Professionalization of teaching, according to Osuji (2007:1) refers to advancement in relevant education and training of primary and secondary school teachers for advancement of moral behaviour, attitude, knowledge and skills towards effective performance. This idea of professionalization is equally necessary in all sectors of education including adult and non- formal education in Nigeria.

In a similar vein, Osho (2012:1) posits that the

Professional development of teachers generally refers to the regular intellectual inducement and technical know-how of the trainers of future leaders worldwide, to meet the challenges of quality of education. And the effective and professional development of teachers is vital to the quality of education; the socio-economic; and political development as well as the scientific discovery that are crucial to make the world a better place in the $21^{\text {st }}$ Century (http//www.africanoutlookonline.com/index.php?).

The National Policy on Education (2004) Section 8(b) earmarked the following as its goals in relation to teacher education, these are mainly to:

i) produce highly motivated, conscientious and efficient classroom teachers for all levels of our educational system,

ii) encourage further the spirit of enquiry and creativity in teachers,

iii) help teachers to fit into social life of the community and the society at large and enhance their commitment to national goals,

iv) provide teachers with the intellectual and professional background adequate for their assignment and make them adaptable to changing situations,

v) enhance teachers' commitment to the teaching profession.

It further added that all teachers in educational institution shall be professionally trained. Afolabi and Loto 
(2012) note that 'The National Policy on Education of 1977 which contains a philosophical anchorage for the development of education in Nigeria by placing high premium on lifelong education, would remain the first document in post-independence Nigeria that has national effect throughout the federation. Teacher education programmes shall be structured to equip teachers for the effective performance of their duties. Before this period, Awotua-Efabo (cited in Nmom 2012:45) highlights certain obstacles to the professionalization of teaching and these include (i) the fact that teachers were not required to be licensed as a prerequisite to teach in the classroom, the erroneous notion that any untrained teacher could be enlisted to teach, the poor remuneration of teachers, the materialist conception which made financial reward a yardstick for measuring fulfilment in the teaching profession, an un-conducive teaching environment and the difficulty in setting minimum standards for teaching. But with the creation of the Teachers Registration Council of Nigeria, the sector has witnessed some transformation.

\section{The Provision Of The Teachers Registration Council Decree No 31 Of 1993}

It is against the backdrop of the Government's position that "teaching is a legally recognized profession in Nigeria". In this regard, Government has set up the Teachers registration Council of Nigeria to control and regulate the practice of the profession. There was a caveat that those already engaged in teaching, but not professionally qualified shall be given a period of time within which to qualify for registration or leave the profession.

The Teacher registration Council of Nigeria produced a Teacher Code of Conduct and Section 5 contains the Teacher registration Act No. 31 of 1993 with the following provisions:

a) The functions of the TRC: The Teachers Registration Council was established by the Act of No. 31 of 1993. The Act charges the Council with the following functions among others.

i) Determining who are teachers for the purpose of this Act.

ii) Determining what standards of knowledge and skills are to be attained by persons seeking to become registered "as teachers under this Act and raising those standards from time to time as circumstances may permit.

iii) Securing in accordance with the provisions of this Act the establishment and maintenance of a register of teachers and the publication from time to time of the lists of those persons.

iv) Regulating and controlling the teaching profession in all aspects and ramifications.

v) Classifying from time to time, members of the teaching profession according to their levels of training and qualification.

vi) Performing through the Council established under this Act, the functions conferred on it by this Act. The TRC Act Section 9(6) empowers the Council to make rules which are not inconsistent with the Act as the acts which constitute professional misconduct and this comes under the Teachers Code of Conduct. There is also the Teachers Investigation Panel (TIP) which is charged with the responsibility of investigating the actions of erring members of the profession where they are involved in any misconduct. The Panel is expected to exist in all the states of the Federation and the Federal capital Territory, Abuja. TRC Act also provides for the setting up of the Teachers' Disciplinary Committee (TDC) which deals with cases referred to it by the TIP and where the erring teacher in question is found to be culpable, the level of punishment will be determined and appropriate measures taken.

To erring members, the TDC may award penalties such as:-
a) Advice.
b) Reprimand
c) Suspension for months and
d) Deletion of name temporarily or permanently from the Teachers Register.

The TRC Act document under chapter two, Principles of professionalization of Teaching in Nigeria, provides for the categorization of teachers as follows:

A-Class: Holders of Ph.D. in Education or Ph.D. in other fields plus Education (e.g. P.G.D.E., N.C.E.)

B-Class: Holders of Masters' Degree in education of Master in other field plus Education (e.g.

P.G.D.E., N.C.E.)

C-Class: Holders of Bachelor's Degree in education or Bachelors $\quad$ in other fields plus Education (e.g.

P.G.D.E., N.C.E.)

D-Class-Holders of Nigeria Certificate in Education (N.C.E.) or equivalent.

A clause in the documents upholds that holders of TCII and equivalent shall be given provisional registration, which shall expire at the end of 2006. Section 7 of the TRC Act emphasizes Legal requirements which states further that, to be registered, an individual must:

a) Pass a qualifying examination accepted by the Council and Complete the practical teaching prescribed by the Council under the Act or

b) Not being a Nigerian, hold a qualification granted outside Nigeria which for the time being is recognized 
by the Council and is by law entitled to practice to the profession in the country in which the qualification was granted provided that the other country accords Nigeria professional teachers the same reciprocal treatment and that he satisfies the Council that he has had sufficient practical experience as a teacher.

c) Be of goods character.

d) Have attained the age of twenty one years.

e) Not have been convicted in Nigeria or elsewhere of an offence involving fraud or dishonesty, other requirements of the TRC Act are:-

1. Internship after graduation from school.

2. Licensing

3. Mandatory Continuing Professional Educations.

4. Annual subscription and

5. Any other requirements that may be made from time to time.

Under Section 9, we have Obligations of teachers as follows:-

a) Professional Standards: Teachers should seek to achieve the highest professional standards in all their works and uphold the honour and integrity of the profession.

b) Professional Commitment: Teachers should have an enduring absolute commitment to the profession, giving maximum attention and responsibility to the profession aspiring to make a successful career within the system, and taking pride, in the profession.

c) Efficiency: Teachers should render efficient and cost effective professional service at all times.

d) Evaluation of learners' performance: Teachers should evaluate periodically the learner's performance and render all professional assistance likely to enable the learner to identify and excel in their skills.

e) Precepts: Teachers should be dedicated and faithful in all professional undertaking being punctual, thorough, conscientious and dependable.

f) Arbitration: Teachers should submit themselves to the summons and arbitration of Teachers Investigation Panel and Teachers Disciplinary Committee as and when the need arises.

Under Section 10, the Rights and Privilege registered teacher shall enjoy include:-

a) Legal status as teachers

b) Freedom to attach to their names, titles or prefixes as may be determined by TRC for the identification of registered teachers in Nigeria.

c) Freedom to impart their professional skills, knowledge and values within the education system, subject to regulation by TRC

d) Participation in all TRC activities that are opened to members.

e) Letter of credence from TRC when required by foreign teachers Council or other relevant bodies around the world.

f) Professional salary, allowances and other benefits that may be secured by the TRC for registered teachers.

To further pursue the professionalization of teaching in the country, Obagah (2007:238) posits that the

Nigerian Union of Teachers (NUT)" established the institute of Certified Teacher of Nigeria in the Year 2000 to; ensure the formal registration of all trained teachers. Their goals are as follows:-

i) To define standards in teaching.

ii) To continuously use those defined standard as instrument of educational advancement

iii) To expose practicing teachers to current trends in pedagogy as an instrument for facilitating the attainment of high standards.

iv) To broaden the professional outlook of teachers through the provision of varied and copious resources materials.

v) To provide the necessary forum for teachers to exchange views on current trend in pedagogy.

vi) To offer outlets for publishing those views widely for the benefit of all its members.

vii) To repeatedly remind teachers of the need for true partnership with parents in their efforts to bring up the children properly both within and outside the school.

viii) To make professional contributions to the planning policy making and administration of Education.

ix) To establish ethical codes for the profession.

$\mathrm{x}$ To conduct courses, along with other bodies, and set appropriate and upward mobility of members at all levels.

xi) To work with other professional associations in areas of common interest.

xi) To promote and give recognition to professional excellence.

xii) To accommodate all professional association which emphasize skills in teaching under one umbrella. The work of Olulube Unah and Agbor (2013:56) identify the critical role of education policies in fostering social change in society 


\section{A Critical Analysis Of The Teachers, Registration Council Act 31, 1993 And Recommendations}

Irrespective of the provision of the TRC under Act 31, 1993 Alaba (2006:4) notes that there are basically three categories of teachers in a land; these are as follows:-

i. Professional Teachers: which includes holders of the National Certificate in Education (N.C.E.), Associate Certificate in Education Certificate holders of Grades I and II Teachers, Bachelor degree holders (B.ED), Bachelor of Science (Education) and Bachelor of Art (Education).

ii. Non Professional Teachers: These are degree and advanced Technical and Commercial Certified qualification.

iii. Auxiliary Teachers: These are individuals with inter-mediate and craft certificates as well as West African School Certificate (WASC) and General Certificate examination (G.C.E) which are common in private schools. This unofficial classification brings to the fore the issue of wide scale awareness, among the generality of teachers. Much effort I should be geared towards ensuring that the provisions of the TRC are made public through workshops, seminars and conferences. Regrettably it is on record that more than $83 \%$ of teachers in Nigeria do not attend academic conferences.

The hallmark of the Act 31, TRC in Section 6 is that the minimum qualification for teaching in Nigeria is the National Certificate in Education (N.C.E). Thus only trained teachers will be admitted into the teaching profession. A close examination of the realities on ground will reveal a wide between policy formulation and policy implementation.

In most state of the federation, untrained teachers are still employed to fill vacant positions. To achieve the objective of the TRC with regard to professionalization, our decision makers in the education sector should be firm in enforcing the professional requirement. For specialist teachers without the required educational qualification they should be encouraged to enroll in post graduate diploma programmes in education to remedy their deficiencies. The Federal, State and Local Government should demonstrate sincere commitment to the ideals of the TRC. The Teacher should be accorded proper recognition in the entire scheme, Morrison (2003: 43), notes that in an advanced country like America "teachers are involved in a wide range of responsibilities that involve leadership and decision making. He views the professionalization of teaching as a process of making teaching a better and more authentic profession through agreed-on standards of practice and regaining of public confidence in the schools abilities to educate all students well. It is expected of Government Agencies to enforce the professional requirement for teaching in all strata of our educational system ranging from primary, secondary and tertiary.

Another critical issue is that of teachers' welfare and remuneration. It' is heart-warming to note that the status of the teacher has received international attention with the declaration of the Teachers' Day on every, October 5 of every year by United National Organization (UNO). In the last World Teachers day in Nigeria, the National body of the National Union of Teachers (NUT) seized the opportunity to remind the Government to implement the Teachers' Salary Scale (TSS) as provided by Decree 31 of the TRC. Most teachers are poor and majority, from the research findings of Osuji (2007:7) may not want their children to take to teaching as a profession because of what they consider unrewarding nature of the career.

Another area of special consideration is funding and financial assistance. Obanya (2002:208) observes that funding is a fundamental factor in realizing educational objectives not only in Nigeria but also in the entire African Continent. The Government should embark on fiscal allocation that will provide enough physical infrastructures and in structural materials available as this will aid the training and retraining of teachers. Maduagwu's (1995:122) work reveals that in India, the Government is actively involved in educational policies and makes budgetary allocation for Government approved schools by way of grants and aids. While acknowledging the contribution of the various tiers of Government in Nigeria, it must be stated that the Government has not done enough. Most primary and secondary schools in the rural areas do not have adequate physical infrastructure that will make for effective learning. It is difficult nowadays to talk of in- service training for teachers (Wakili 1999: 144).

In Rivers State as in other States in Nigeria the morale of teachers in attending workshop is very low. Often times they are invited to the secondary school for a seminar or workshop where they are required to spend almost eight hours daily for about three days. In most cases, these teachers are not given instructional materials or seminar papers neither are they given transport allowance to and fro. In the same vein, most teachers are not sponsored to attend academic workshops organized by bodies like the Science Teachers' Association of Nigeria (STAN) and Allied bodies.

It is also sad to observe that in Rivers State, most teachers are disillusioned for obvious reasons. In most cases their promotions are not regular and when eventually they are elevated, the financial benefit does not reflect the year of actual promotion. In addition, teachers work tirelessly without normal yearly increments mainly in the secondary school arm. Most times, their allowances as house master, form masters etc. are not paid. It is my candid opinion that the Government Agencies like the Rivers State Universal Basic Education Board and 
Ministry of Education should address critical issues bordering on staff welfare. When compared to other States, the case of Rivers State is even better because the Government has to an extent implemented the New Teachers' Salary Scale (TSS).

To achieve the noble goals of professionalism in Nigeria, there should be an effective monitoring and control by supervising agents. The laze-affair attitude of most Ministries of Education and Schools Boards supervisors are not encouraging. Issues such as punctuality of teachers, commitment to work as borne out by quality preparation of teachers with their notes of lesson intact should be vigorously pursued. The incessant occurrences of truancy of teachers must be curbed. The Government can assist in this area by ensuring that teachers sign the movement register before going out.

To also aid the realization of professionalization, teachers' appraisal by promotion should include the participation in workshop and on academic seminar as a condition. Part of the requirement for promotion should also be evidence of registration with the Institute of Certified Teachers of Nigerian (CTON). The TRC Act 31 provides for continuous training. Practitioners in the medical profession go for refresh courses to update their knowledge and teachers should follow suit.

Regular workshop for teachers will not only update their knowledge of teaching skills but also assist to tackle the challenges posed by policy changes in the educational sector such as the transition from the Universal Primary Education (UPE) scheme to the current Universal Basic education (UBE) programme.

\section{Summary And Conclusion}

From the foregoing, it is crystal clear that the professionalization of teaching in Nigeria will lay the foundation for a revolution in the educational sector. The Teacher Registration Council Act of 31 of 1993 has made adequate provision covering membership, codes, of conduct and ethics and classification of teachers with a package in the enhancement of the status of the teachers. The only problem is that currently there is a wide gap between policy formulation and policy implementation. It is expected that the implementation of the suggestions made so far, the tide will turn for the better for the teaching profession in Nigeria.

\section{References}

[1]. Adenuga, R. A. (2007): Qualitative Teacher education: Panacea to School Leadership and Professionalism (Downloaded) from Internet.

[2]. Adeyideino, S. C. (1998) National Policy on Education: Formulation and Implementation (An Assessment) in Tamuno, T. N. and Atanda, J. A (Eds) Nigeria Since Independence, The First 25 years Vol. III Education, lbadan. Heinemann Educational Brok Limited.

[3]. Afolabi, F.O and Loto, A.B (2012) Socio-political vicissitudes and bureaucratic constrains on educational policy formulation and implementation in Nigeria. In Edo, V.O \& Salami, E. F.K (eds) Issues and trends in Nigeria's development, A Festschrift for The Rev. (Fr.) Abiodun F. Akinseye: John Archers (Publishers) Ltd

[4]. Fafunwa, A. B. (1989) National Policy on Education: A Planner's Viewpoint in Tammuno, T. N. and Atanda, J. A. Nigeria Since Independence, the First 25 Years Vol. III, Education.

[5]. Maduagwu, S. N. (1995): Development of Primary and secondary Education in India and Nigeria in Kosemani, J. M. (ed) Comparative education, Emergant National Systems., Port Harcourt; Abe publishers.

[6]. Minister restates commitment to professionalise teaching profession. $\mathrm{http} / \mathrm{www}$.nanngronline.com/section/general/ministerrestates.com

[7]. Morrison, G. S. (2003): Teaching in America Boston: Peason education, Inc.

[8]. Nmom, C. (2012) The professional social studies teacher. Nature, functions and freedom to teach. In International Journal of Educational Development. 2(2)

[9]. Obagah, M. 0. N. (2007 Edition): Internship Design, Organisation and evaluation, Across educational, Scientific, and Social Sciences Curriculums, Port Harcourt: Zelon Publishers.

[10]. Obanya, P. (2002): Revitalizing education in Africa, lbadan: Stirling Hordes Publsihers.

[11]. Okeke, B.S. (2004): Teaching in Nigeria The Bureaucracy and Professionalism, Port Harcourt Mercury International Publishing Nigeria.

[12]. Ololube, N.P, Uriah, O .A \& Agbor, C. N (2013) The nature of social change and its implications for educational management and planning. In International Journal of Educational Foundations \& Management 1(1)

[13]. Osho, S. A (2012) Professional development of teachers in the Century.http://www.africanoutlookonline.com/index.php?option=com cont

[14]. Osuji, S. N. (2007) Teachers' Conception of Professionalization of Teaching in Nigeria (Downloaded from Internet Websites)

[15]. Uya, O. E (2012) education and democracy: the continuing dialectic. In Mbua, D., Akpan, O., Amadi, I \& Ochefu, Y. (eds.) History, Culture, diasporas and nation building. The Collected Works of Okon Edet Uya. Bethesda: Arbi Press.

[16]. Wakili, A. J. and Jatan, M. K. (1999): Effective Education for Niational Development and Survival Beyond the Year 200 in Nigeria in Akinbi, J. 0. (ed) Towards a Better Nigeria, Reflection'on Contemporary Ismes in the Socio-Political and Economic development of Nigeria, lbadan; Ben Quality Prints.

[17]. Teaches Code of Conduct, Teacher registration Council, Act 31, 1993.

[18]. National Policy on Education (2004) 41" edition, Federal Republic of Nigeria. 